\title{
Cyathus olla from the cold desert of Ladakh
}

\section{Dorjey K, Kumar S and Sharma YP}

Department of Botany, University of Jammu, Jammu, J\&K, India-180 006

E.mail: yashdbm3@yahoo.co.in

Dorjey K, Kumar S, Sharma YP 2013 - Cyathus olla from the cold desert of Ladakh. Mycosphere 4(2), 256-259, Doi 10.5943/mycosphere/4/2/8

Cyathus olla is a new record for India. The fungus is described and illustrated. Notes are given on its habitat and edibility and some ethnomycological information is presented

Key words - ethnomycology - new record - taxonomy

Article Information

Received 8 February 2013

Accepted 13 March 2013

Published online 28 March 2013

*Corresponding author: Sharma YP - e-mail - yashdbm3@yahoo.co.in

\section{Introduction}

Cyathus is the most common genus in the family Nidulariaceae (Nidulariales, Gasteromycetes). The genus, with cosmopolitan distribution, is distinguished from the other four genera in the Nidulariaceae (Crucibulum, Mycocalia, Nidula, Nidularia) based on grey to black peridioles with funicular cords and peridia composed of three layers of tissues (Brodie 1975). Kirk et al. (2008) included 45 species in this genus and placed it in the family Agaricaceae. In India, 15 species have been recorded from various locations, however, there is no record of the genus Cyathus from Jammu and Kashmir State (Bilgrami et al. 1979, 1981, Jamaluddin et al. 2004). The present communication deals with Cyathus olla (Batsch) Pers., collected from Wanla area of Ladakh (Jammu and Kashmir) and constitute a new record for India.

\section{Materials and methods}

Field records were made for macroscopic features of fruiting bodies and their habitat. Microscopic observations were made by mounting the dried materials in $5 \%$ ethanol and 3\% aqueous $\mathrm{KOH}$ solution, and then staining with $1 \%$ aqueous Congo red. For statistical calculation of size ranges, more than 20 basidiospores, basidia and other elements were measured. Identification and description was done by using relevant literature (Smith et al. 1981, Arora 1986, Kirk et al. 2008). The examined samples were deposited in the herbarium of Botany Department, University of Jammu.

\section{Results}

Cyathus olla (Batsch) Pers., Syn. meth. fung. 1: 237 (1801)

Peziza olla Batsch, Elench. fung.: 127 (1783)

Collection examined - Humicolous as well as lignicolous, scattered, in cultivated field of Hordeum vulgare and mixed forests of Salix excelsa, S. alba, Populus nigra and $P$. caspica, Wanla area, Leh, Ladakh, Jammu and Kashmir, K. Dorjey, S. Kumar and Y. P. Sharma, BHJU-201 (Holotype), 5 August 2011. Fruiting body $-1.0-1.5 \mathrm{~cm}$ high, $0.7-$ $1.0 \mathrm{~cm}$ wide, cup or funnel shaped, light brown to greyish, exterior surface rough and covered with minute smooth hairs, inner surface smooth and shiny, and silver to blackish. The fruiting body entirely closed in young stages and fully or partially exposed in mature specimens. 


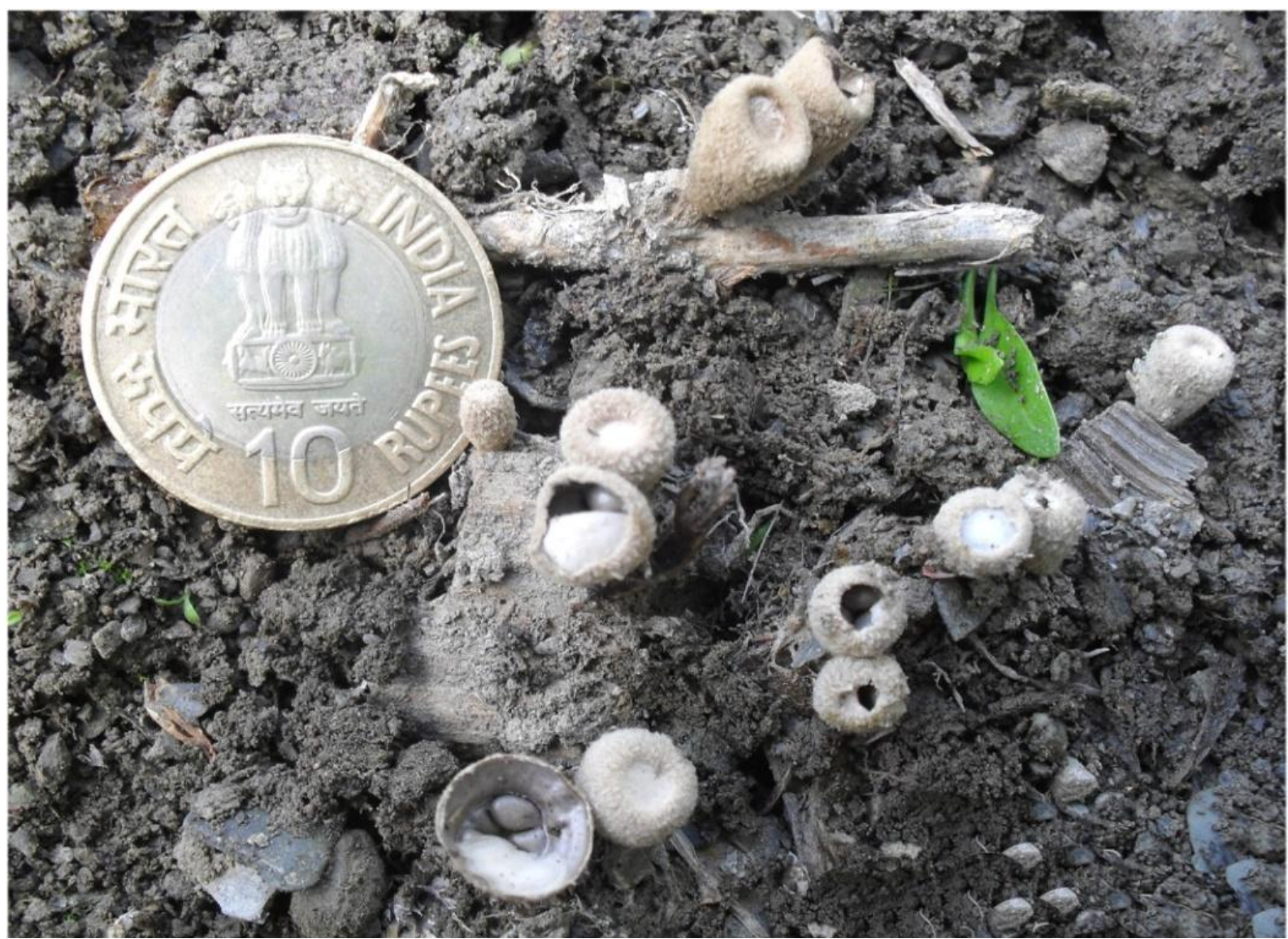

Fig. 1 - Fruiting bodies of Cyathus olla in natural habitat.

Epiphragm thick, pale whitish and persistent.Margins circular and entire when young but wavy at maturity; eggs or peridioles about $2-3 \mathrm{~mm}$ in diameter and attached to base of peridium by a funicular cord. Peridioles 11 in number, oval or egg-shaped pure silver to blackish. The assemblage of peridioles resembled eggs lying in the bird's nest (Fig.1).

Basidiospores oval to broadly ellipsoidal, $9.8-11.2 \times 6.4-8.0 \mu \mathrm{m}$, hyaline, thin-walled. Basidia claviform, $19.2-35.2 \mathrm{x}$ $6.4-8.8 \mu \mathrm{m}$, hyaline, thin-walled, sterigmata inconspicuous and occasionally two to four sessile spores were observed directly attached to the basidium. Purse hyphae $1.6-4.8 \mu \mathrm{m}$ wide, hyaline, thin-walled, branching very rarely, hyphae swollen at or near the septum to form a bulbous septum. Peridium hyphae $1.6-$ $4.0 \mu \mathrm{m}$, thin-walled, branched, septate. Clamp connections present occasionally (Fig. $2 \mathrm{a}-\mathrm{e}$ ).

Edibility - Not edible in the study area.

Remarks - A new record for India from Ladakh region of Jammu and Kashmir State.

\section{Ethnomycology of $C$. olla in Ladakh}

In several villages in Ladakh, this bird's nest fungus is locally referred to as "Nasibaangah'. The term Nasi-baangah is a combination of two words - 'Nasi' which is taken from 'Nass' meaning wheat or barley grain and 'baangah' which refers to the traditional storage bins made up of mud bricks. Therefore, the local inhabitants compared Cyathus olla with a granary used for storing grains. The vase-shaped peridium of fungus resembled storage structures and the peridioles inside them were considered as grains. One of the most incredible beliefs among the local folks was that locating this fungus in a group of seven or more in their cultivated fields at the time of crop harvesting, was blissful. In addition, appearance of a large number of fruiting bodies of Cyathus in an area during harvesting season (July - August) was believed to be a sacred omen that would bring good fortunes to the community in the form of bumper grain production thereby adding 

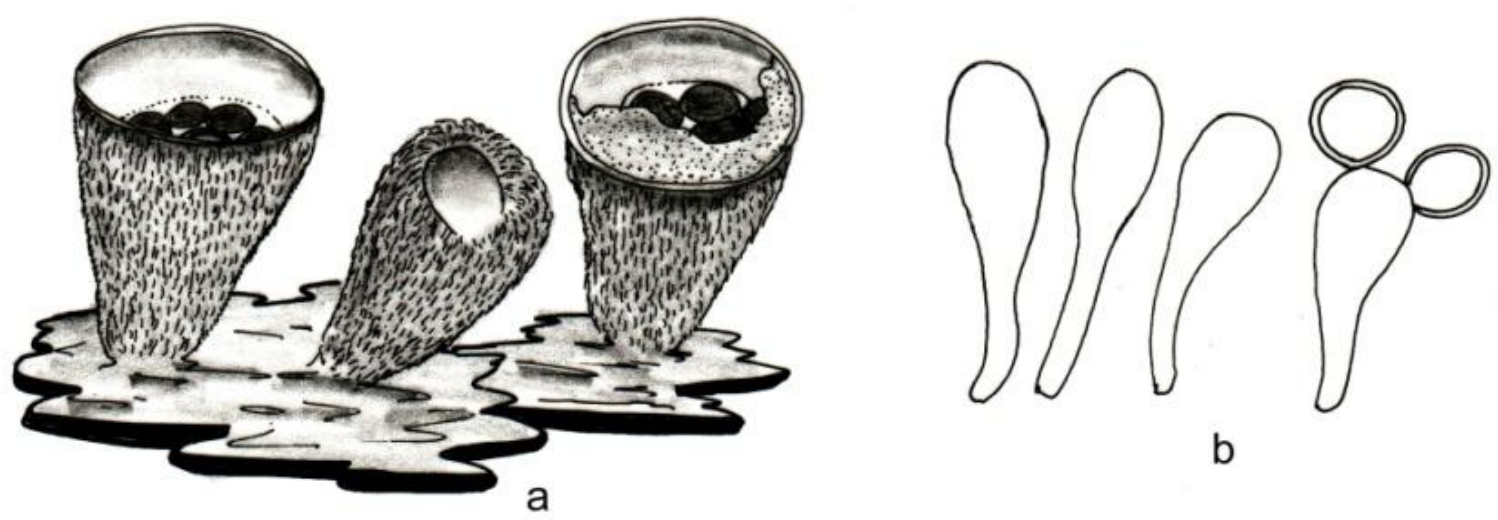

b

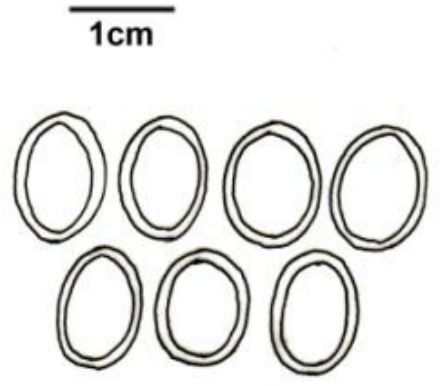

C
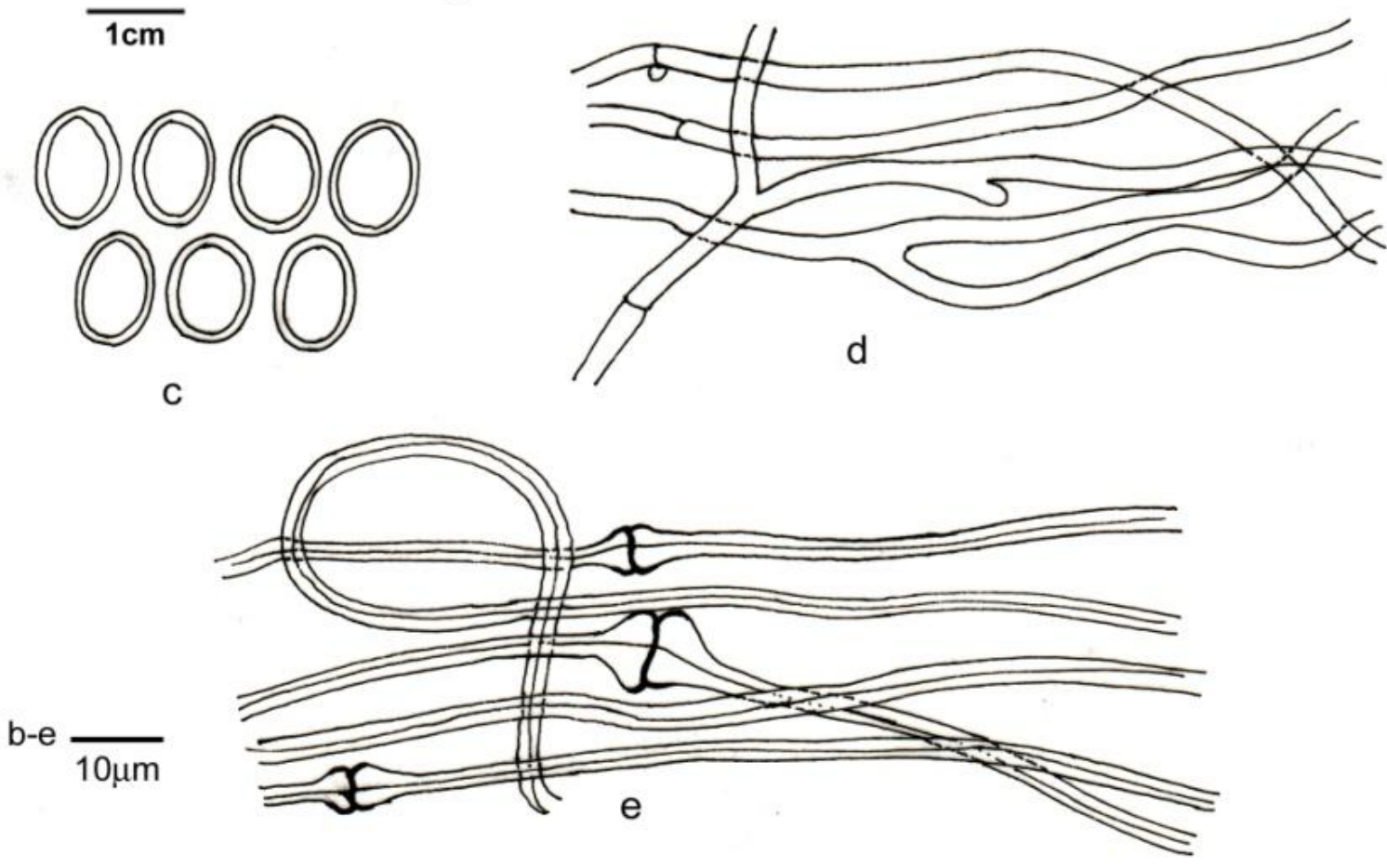

Fig. 2 - Cyathus olla. a hand drawn sporophores; camera lucida drawings of $\mathbf{b}$ basidia c basidiospores $\mathbf{d}$ peridium hyphae e purse hyphae

credence to the spiritual and religious significance of Cyathus olla.

\section{Discussion}

Cyathus olla is characterized by a small cup or vase-shaped structure with lid (epiphragm) very similar to C. striatus (Huds.) Willd., but the sporophore of the former is tomentose outside, shiny, silver to blackish and smooth inside in contrast to the striations on the inside surface of conical sporophores in the latter. Further, the size and colour of peridioles and their attachment to the funiculus corroborates with the previously described specimens of C. olla (Cunningham 1924, Soothill \& Fairhurst 1978).

Besides its distribution in North America, C. olla is the most abundant species in Europe. Its range extends north to Sweden and far south in South America; it has also been reported from South Africa, Iran, Australia and China (Brodie 1975, Liu \& Li 1989, Yang et al. 2002, Zhou et al. 2004). The species, however, was not previously reported from India and, therefore, is a new record from the Ladakh region of Jammu and Kashmir State. The existence of this species in the cold arid desert of Ladakh indicates its tolerance to 
extreme freezing temperatures and poor moisture conditions of Ladakh. This assumption is based on the studies of Brodie (1975) who revealed that $C$. olla usually occupies moist and shady locations while its discovery in the arid regions of Peru (Brodie 1977) suggests its endurance to low-moisture conditions as well.

\section{Acknowledgements}

Authors (Dorjey K) wish to thank University Grant Commission (UGC), New Delhi for financial assistance as Junior Research Fellowship (JRF) and Department of Botany, University of Jammu, Jammu for providing laboratory facilities.

\section{References}

Arora D. 1986 - Mushroom Demystified: A comprehensive guide to fleshy fungi. Ten Speed Press, Berkeley, California, pp. 936.

Bilgrami KS, Jamaluddin, Rizwi MA. 1979 Fungi of India, Part-I. List and References. Today and Tomorrow's Printers and Publishers, New Delhi, pp.467.

Bilgrami KS, Jamaluddin \& Rizwi MA. 1981 The Fungi of India. Part II. Host Index and Addenda. Today and Tomorrow's Printers and Publishers, New Delhi, pp.140.
Brodie HJ. 1975 - The Bird's Nest Fungi. University of Toronto Press, Toronto, Canada. pp. 200.

Brodie HJ. 1977 - A key of the species of Cyathus (Nidulariaceae). Bot. Notiser. 130, 453-459.

Cunningham GH. 1924 - A Revision of the New Zealand Nidulariales, or "Birds-nest Fungi”. Cunningham pp. 59-66.

Jamaluddin, Goswami MG, Ojha BM. 2004 Fungi of India. Scientific Publishers, India, pp. 326.

Kirk PM, Cannon PF, Minter DW, Stalpers JA. 2008 - Ainsworth and Bisby's "Dictionary of the Fungi" (10 ${ }^{\text {th }}$ edition). CAB International, Wallingford, UK, pp. 771.

Liu B, Li YM. 1989 - New species and new varieties of Cyathus. Acta Mycologica Sinica 8, 101-112.

Smith AH, Smith HV, Weber NC. 1981 - How to Know the Non-gilled Mushrooms. Wm. C. Brown Company Publishers Dubuque, lowa, pp. 317.

Soothill E, Fairhurst A. 1978 - The New Field Guide to Fungi. Michael Joseph, London, pp. 191.

Yang B, Yu J, Zhou TX. 2002 - Two new species of the genus Cyathus from western China. Mycosystema 21, 313315.

Zhou TX, Zhao LZ, Zhao RL, Chen YH. 2004 - Bird's nest fungi from China. Fungal Diversity 17, 243-251. 